\title{
KEMAMPUAN BAKTERI DIAZOTROF ENDOFIT UNTUK MENINGKATKAN PERTUMBUHAN VEGETATIF BIBIT KELAPA SAWIT (Elaeis guineensis jacq)
}

\section{Ability of Endophytic Diazotrophic Bacteria in Stimulating Growth of Oil Palm Seedlings (Elaeis guineensis Jacq)}

\author{
Andreas Panjaitan ${ }^{1}{ }^{*}$, Iswandi Anas'), Rahayu Widyastuti2), dan Wiwik Eko \\ Widayati ${ }^{3}$ \\ 1) Staff Riset and Development Department, PT. Swakarsa Sinarsentosa, Jakarta \\ 2) Departemen Ilmu Tanah dan Sumberdaya Lahan, Fakultas Pertanian IPB, Jl. Meranti Kampus IPB Darmaga \\ Bogor 16680 \\ 3) Pusat Penelitian Perkebunan Gula Indonesia, Jl. Pahlawan, Pasuruan-Jawa Timur
}

\begin{abstract}
Endophytic diazotrophic bacteria are free-living atmospheric dinitrogen fixing bacteria that lived and colonized between living plant cells and do not contribute phatogenic effects to its host. The ability of endophytic diazotrophic bacteria in providing nitrogen as nutrient for crop plays an important role in reducing dependency of inorganic nitrogen fertilizer. The aim of this experiment was to study the ability of endophytic diazotrophic bacteria isolate to stimulate vegetative growth of oil palm seedlings at four levels inorganic nitrogen fertilizer application. Experiment was conducted at the greenhouse IPB Campus, Cikabayan, Darmaga with the altitude of $250 \mathrm{~m}$ above sea level and at the Soil Fertility Laboratory, the Departement of Soil Science and Land Resources, Faculty of Agriculture, Bogor Agricultural zuniversity (IPB) and at the Laboratorry of Biotechnology, Indonesian Sugarcane Research Centre (P3GI) Pasuruan, East Java. This experiment using Completely Randomized Block Design (CRBD) consisted of two factors with three replications. The first factor was inorganic nitrgen levels consisted of four levels (0,50\%, 75\% and 100\% of recommended dose). Second factor was inoculation with endophytic diazotrophic bacterial isolates consisted of four levels; without inoculation, inoculated with isolate 1, isolate 2 and isolate 3. The results of the experiment showed that the innoculation with bacterial isolate 2 without $N$ fertilizer appllication gave the best results to increase the diameter of the palm weevil, palm height, and dry weight. In addition to that, the application of endophytic diazotrophic bacteria isolate was able to promote vegetative growth of palm oil seedling.
\end{abstract}

Keywords: Endophytic diazotrophic bacteria, nutrient up-take, oil palm seedling, vegetative growth

\section{ABSTRAK}

Bakteri diazotrof endofit adalah bakteri penambat $\mathrm{N}_{2}$ yang hidup berkoloni di dalam jaringan tanaman tetapi tidak memberikan efek patogenik terhadap tanaman inangnya. Kemampuan bakteri diazotrof endofit dalam menyumbangkan hara nitrogen bagi tanaman diharapkan akan sangat berperan dalam mengurangi ketergantungan aterhadap pupuk nitrogen anorganik. Percobaan ini bertujuan untuk mempelajari kemampuan isolat bakteri diazotrof endofit yang diaplikasikan dengan pupuk nitrogen terhadap pertumbuhan tanaman dan bobot kering bibit kelapa sawit. Percobaan dilakukan di rumah kaca kebun Percobaan IPB, Cikabayan, Darmaga dengan ketinggian sekitar 250 m dpl dan di Laboratorium Kesuburan Tanah, Departemen Ilmu Tanah dan Sumberdaya Lahan IPB serta di Laboratorium Bioteknologi Pusat Penelitian Perkebunan Gula Indonesia (P3GI) Pasuruan, Jawa Timur. Percobaan ini menggunakan metode Rancangan Acak Kelompok (RAK) terdiri dari dua faktor dengan tiga ulangan. Faktor pertama yaitu dosis $\mathrm{N}$ yang terdiri dari empat taraf (0, 50\%, 75\% dan 100\% standar pemupukan). Faktor kedua yaitu aplikasi isolat bakteri diazotrof endofit terdiri atas 4 taraf yaitu tanpa inokulasi, diinokulasi dengan isolat 1, isolat 2 dan isolat 3. Hasil penelitian menunjukkan bahwa kombinasi inokulasi isolat bakteri diazotrof endofit dengan tanpa pemupukan nitrogen memberikan hasil pertumbuhan vegetatif terbaik untuk bibit kelapa sawit yaitu diameter bonggol, tinggi bibit, dan berat kering bibit kelapa sawit.

Kata kunci : Endofit bakteri diazotrof, pengambilan hara, bibit kelapa sawit, pertumbuhan vegetatif

\section{PENDAHULUAN}

Peningkatan luas areal perkebunan kelapa sawit berakibat kebutuhan pupuk anorganik terus meningkat. Belakangan ini harga bahan baku pupuk meningkat pesat yang menyebabkan harga pupuk anorganik semakin mahal. Di sisi lain, penggunaan pupuk anorganik dengan takaran yang berlebihan akan mencemari lingkungan, dapat mengganggu kesehatan tanaman serta meningkatkan biaya produksi.

Upaya pemanfaatan bakteri diazotrof (penambat $\mathrm{N}_{2}$ ) sebagai pupuk hayati telah banyak dilakukan namun karena pemahaman ekologi mikrob yang diaplikasikan belum memadai maka hingga saat ini upaya tersebut belum 
memberikan hasil yang konsisten. Salah satu hal yang patut dicermati dalam upaya pemanfaatan pupuk hayati adalah pola interaksi yang terjadi antara bakteri diazotrof dengan tanaman inangnya (Zinniel et al., 2002; Widayati, 2005).

Beberapa bakteri diazotrof diketahui mampu hidup dan menyumbangkan sekitar $70 \%$ kebutuhan total $\mathrm{N}$ pada beberapa varietas tanaman tebu (Urquiaga et al., 1992). Bakteri diazotrof tersebut diketahui mampu hidup secara endofit dalam tanaman tebu dan berkolonisasi pada xylem tebu (James et al., 2001).

Istilah endofit digunakan untuk menunjukkan adanya kolonisasi mikrob di dalam jaringan tanaman tetapi tidak memberikan efek patogenik terhadap tanaman inangnya (Zinniel et al., 2002). Beberapa jenis bakteri endofit diketahui berperan penting dalam menunjang vitalitas tanaman. Hasil penelitian menunjukkan bahwa bakteri endofit berfungsi sebagai penambat $\mathrm{N}_{2}$ (Lee et al., 2000), penghasil fitohormon dan siderofor (Feng et al., 2006), agen pengendali hayati, meningkatkan daya tahan terhadap serangan patogen dan parasit (Reiter et al., 2002), pendegradasi polutan pada rizosfir serta memproduksi antibiotik (Barac et al., 2004).

Lee et al. (2000) menyebutkan bahwa bentuk interaksi endofit merupakan prototype interaksi mikrob dengan tanaman yang perlu dipelajari karena terbentuk kondisi yang lebih sesuai untuk transfer nutrien di antara keduanya. Keberadaan bakteri endofit di dalam jaringan tanaman lebih menguntungkan terutama dalam hal proteksi aktifitas nitrogenase terhadap $\mathrm{O}_{2}$ (James et al., 2001).

Sampai saat ini belum banyak informasi tentang interaksi mikrob endofit dengan tanaman kelapa sawit. Oleh karena itu, untuk mengupayakan pemanfaatan bakteri endofit tersebut perlu segera dilakukan eksplorasi peran mikrob endofit untuk mengoptimalkan pertumbuhan tanaman kelapa sawit. Penelitian ini bertujuan untuk mengetahui kemampuan asosiasi isolat bakteri diazotrof endofit dengan bibit kelapa sawit dan pengaruhnya dalam meningkatkan pertumbuhan bibit kelapa sawit pada empat taraf pemupukan nitrogen.

\section{BAHAN DAN METODE}

Penelitian ini dilaksanakan di rumah kaca IPB, Cikabayan - Darmaga, Bogor. Analisa tanah dan hara jaringan tanaman dilakukan di Laboratorium Kimia dan Kesuburan Tanah, Departemen Ilmu Tanah dan Sumberdaya Lahan, Fakultas Pertanian, Institut Pertanian Bogor. Pengamatan keberadaan isolat bakteri diazotrof endofit di dalam jaringan tanaman dilakukan di Laboratorium Biologi, Pusat Penelitian Perkebunan Gula Indonesia (P3GI), Pasuruan.

\section{Alat dan Bahan}

Bahan dan alat yang digunakan adalah isolat bakteri diazotrof endofit hasil isolasi dari jaringan akar, batang dan daun kelapa sawit yang tumbuh liar di perkebunan Kalimantan Tengah, tanah Latosol Dramaga, benih kelapa sawit varietas DxP Simalungun-PPKS Medan, gen gfp E. coli PFAJ 1819, antibiotik kanamicin, ampicilin dan rifampicin, pupuk Urea, SP-36, $\mathrm{KCl}$ dan Kieserit, mikroskop fluorescence merk Nikon type 026327.

\section{Metode Penelitian}

Pengujian kemampuan asosiasi isolat bakteri diazotrof endofit dengan bibit kelapa sawit dilakukan melalui pengamatan keberadaan isolat bakteri tersebut pada jaringan akar, batang dan daun tanaman dengan menggunakan mikroskop fluorescence.

Metode penelitian percobaan rumah kaca menggunakan rancangan acak kelompok (RAK) faktorial dengan 2 faktor yaitu :

Faktor I. Dosis hara Nitrogen

$\mathrm{N}_{0}=$ Tanpa pemupukan $\mathrm{N}$

$\mathrm{N}_{1}=$ Dosis pupuk $\mathrm{N}$ sebesar $50 \%$ dari dosis standard PPKS

$\mathrm{N}_{2}=$ Dosis pupuk $\mathrm{N}$ sebesar $75 \%$ dari dosis PPKS

$\mathrm{N}_{3}=$ Dosis pupuk $\mathrm{N}$ sebesar $100 \%$ dari dosis standard PPKS

Faktor II. Jenis Isolat Bakteri Diazotrof Endofit

$\mathrm{I}_{0}=$ Tanpa isolat

$\mathrm{I}_{1}=$ Isolat 1 (diisolasi dari jaringan akar kelapa sawit yang tumbuh liar)

$\mathrm{I}_{2}=$ Isolat 2 (diisolasi dari jaringan batang kelapa sawit yang tumbuh liar)

$\mathrm{I}_{3}=$ Isolat 3 (diisolasi dari jaringan daun kelapa sawit yang tumbuh liar)

Isolat yang digunakan adalah isolat bakteri diazotrof wild type (isolat tanpa penanda gen $g f p$ ) koleksi PT Swakarsa Sinar Sentosa, Jakarta dan P3GI Pasuruan yang berasal dari daerah Kalimantan Tengah. Perlakuan yang diuji terdiri dari 16 kombinasi perlakuan yaitu:

$\begin{array}{llll}\text { 1. NOIO } & \text { 5. NOI1 } & \text { 9. NOI2 } & \text { 13. NOI3 } \\ \text { 2. N1I0 } & \text { 6. N1I1 } & \text { 10. N1I2 } & \text { 14. N1I3 } \\ \text { 3. N2I0 } & \text { 7. N2I1 } & 11 . \mathrm{N} 2 \mathrm{I} 2 & 15 . \mathrm{N} 2 \mathrm{I3} \\ \text { 4. N3I0 } & \text { 8. N3I1 } & \text { 12. N3I2 } & 16 . \mathrm{N} 3 \mathrm{I} 3\end{array}$

Setiap unit percobaan diulang sebanyak tiga kali sehingga terdapat 48 satuan percobaan. Satu satuan percobaan terdiri dari empat bibit kelapa sawit.

\section{Pelaksanaan Penelitian}

\section{Percobaan I. Pengujian Kemampuan Asosiasi Bakteri Diazotrof Endofit dengan Bibit Kelapa Sawit}

1. Penandaan bakteri diazotrof endofit menggunakan gen $g f p$

Tahap trans konyugasi gen dimulai dengan menumbuhkan bakteri E. coli PFAJ 1819 ysng memiliki gen gfp pada media $5 \mathrm{ml}$ Lactose Broth (LB) cair yang mengandung $50 \mu \mathrm{g} \mathrm{ml}^{-1}$ kanamicin dan $50 \mu \mathrm{g} \mathrm{ml}$ ampicilin. Bakteri target ditumbuhkan pada $5 \mathrm{ml}$ media LB cair yang mengandung rifampicin $50 \mu \mathrm{g} \mathrm{ml}{ }^{-1}$ dan diinkubasi selama semalam. Dari masing-masing suspensi bakteri diambil $1 \mathrm{ml}$ kemudian dicampurkan dan disentrifugasi pada kecepatan 3000 g selama 15 menit. Supernatannya dibuang, kemudian ke dalam sel bakteri ditambahkan $500 \mu 10 \mathrm{mM} \mathrm{MgSO}_{4}$. Selanjutnya suspensi bakteri disentrifugasi kembali pada kecepatan $3000 \mathrm{~g}$ selama 15 menit. Pelet yang terbentuk disuspensi dalam 30 $\mu 10 \mathrm{mM} \mathrm{MgSO}_{4}$. 
2. Pengujian sifat asosiasi endofitik bakteri pada bibit kelapa sawit

Bakteri transkonyugan yang mengandung gen gfp ditumbuhkan dalam media LB cair yang mengandung 50 $\mu \mathrm{g} \mathrm{ml}^{-1}$ kanamicin selama semalam dan diinokulasikan ke bibit kelapa sawit dengan cara menyiramkan media LB cair ke permukaan tanah sebanyak $10 \mathrm{ml} \mathrm{polibag}^{-1}$.

3. Visualisasi keberadaan bakteri diazotrof endofit dalam jaringan kecambah kelapa sawit dengan menggunakan Mikroskop Fluorescence merk Canon

Irisan jaringan kecambah kelapa sawit yang telah diinokulasi dengan bakteri diazotrof endofit rekombinan diamati dengan menggunakan mikroskop fluorescence pada perbesaran $100 x$.

\section{Percobaan II. Pengujian Kemampuan Bakteri Diazotrof Endofit untuk Meningkatkan Pertumbuhan Bibit Kelapa Sawit}

Pengujian dimulai dengan membuat media tanah dalam kondisi kering udara, kemudian ditimbang masingmasing sebanyak $1.5 \mathrm{~kg}$ dan dimasukkan ke dalam polibag. Sebelum penanaman kecambah kelapa sawit, tanah di dalam polibag disiram dengan air sampai kapasitas lapang. Kecambah diseleksi hanya yang kondisinya normal (plumula dan radikula lurus) dan ditanam pada kedalaman $1.5 \mathrm{~cm}$ di bawah permukaan tanah.

Bibit kelapa sawit disiram setiap pagi dan sore hari sampai kapasitas lapang ditandai dengan air yang disiramkan mulai keluar dari media tanam bagian bawah. Pada saat aplikasi pemupukan, penyiraman dilakukan setelah aplikasi pemupukan.

Isolat bakteri diazotrof endofit dikulturkan dalam media LB cair dan diinkubasi selama 1 malam (populasi \pm

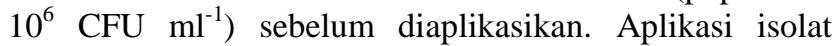
bakteri dilakukan dengan menyiramkan kultur isolat bakteri ke media tanah di sekitar pangkal batang bibit umur 1 bulan sebanyak $10 \mathrm{ml}_{\text {polibag }}{ }^{-1}$.

Pemupukan bibit kelapa sawit dilakukan menggunakan pupuk anorganik urea, SP-36, $\mathrm{KCl}$ dan kieserit. Frekuensi, waktu dan dosis aplikasi pupuk anorganik dilakukan sesuai standar pemupukan bibit kelapa sawit. Dosis standar pupuk anorganik (urea, SP-36, $\mathrm{KCl}$ dan Kieserit) untuk bibit kelapa sawit umur 0-18 MST masing-masing adalah $11.95 \mathrm{~g} \mathrm{bibit}^{-1}, 13.72 \mathrm{~g} \mathrm{bibit}^{-1}, 6.48$ $\mathrm{g}_{\text {bibit }}{ }^{-1}$ dan $4.77 \mathrm{~g} \mathrm{bibit}^{-1}$. Dosis penggunaan pupuk Urea sebagai sumber hara nitrogen disesuaikan dengan taraf dosis perlakuan $(0 \%, 50 \%, 75 \%$ dan $100 \%$ dari dosis standar pemupukan), sedangkan dosis pupuk SP-36, KCl dan kieserit diberikan sesuai dosis standar pemupukan (100\%) untuk seluruh perlakuan.

Peubah yang diamati pada penelitian ini adalah :

a. Kemampuan asosiasi bakteri diazotrof endofit dengan bibit kelapa sawit dilakukan dengan pengamatan waktu tercepat ditemukannya bakteri diazotrof endofit trans konjugan pada jaringan daun bibit kelapa sawit umur 1 bulan, b. Peubah pertumbuhan tanaman berupa diameter bonggol, tinggi dan berat kering total tanaman. Diameter bonggol diukur pada pangkal batang yang membengkak. Tinggi tanaman diukur mulai dari pangkal batang sampai ujung daun tertinggi. Bobot kering tanaman dihitung setelah jaringan tanaman kering oven. Pengukuran diameter bonggol dan tinggi tanaman dilakukan setiap 2 minggu mulai 4 MST sampai 18 MST, sedangkan bobot kering diukur pada akhir penelitian (18 MST).

\section{Analisis Data}

Data dianalisa secara statistik dengan menggunakan analisa sidik ragam pada selang kepercayaan $95 \%$. Pengaruh perlakuan dianalisis dengan uji Duncan pada taraf 5\% (Mattjik dan Sumertajaya, 2006).

\section{HASIL DAN PEMBAHASAN}

\section{Pengujian Kemampuan Asosiasi Bakteri Diazotrof Endofit dengan Bibit Kelapa Sawit}

Kemampuan asosiasi isolat bakteri diazotrof endofit dengan bibit kelapa sawit ditandai dengan keberadaan bakteri diazotrof endofit yang telah diberi gen penanda (bakteri rekombinan) pada jaringan tanaman yang diamati. Pengukuran kecepatan asosiasi bakteri diazotrof endofit dilakukan pada jaringan daun 1 jam setelah aplikasi (JSA) dan 3 JSA dengan bantuan mikroskop fluorescence dengan perbesaran 100x. Keberadaan bakteri rekombinan dapat dilihat dengan adanya cahaya yang berpendar berwarna hijau di dalam jaringan bibit kelapa sawit tersebut.

Keberadaan koloni bakteri diazotrof endofit yang diuji pada jaringan daun bibit kelapa sawit terlihat pada Gambar 1. (ditunjukkan dengan tanda panah). Seluruh isolat bakteri yang diuji sudah ditemukan di dalam jaringan daun bibit kelapa sawit pada 1 JSA, sehingga kecepatan asosiasi masing-masing isolat yang diuji dengan bibit kelapa sawit adalah 1 JSA.

Dari metode inokulasi isolat ke bibit kelapa sawit yaitu dengan cara disiramkan ke media tanah di sekitar pangkal batang diyakini sebagian besar isolat bakteri tersebut masuk melalui jaringan akar bibit kelapa sawit. Hal ini sesuai dengan yang disampaikan oleh Muthukumarasamy et al. (2002) bahwa bakteri diazotrof endofit dapat masuk ke dalam jaringan tanaman melalui akar lateral dan rambut akar. Kecepatan masuknya isolat bakteri diazotrof endofit ke dalam jaringan bibit diyakini berhubungan dengan kesesuaian senyawa penyusun eksudat akar dan asal bakteri diazotrof endofit. Bakteri diazotrof endofit yang diuji seluruhnya diisolasi dari jaringan tanaman kelapa sawit sehingga eksudat akar bibit kelapa sawit lebih sesuai sebagai sumber nutrisinya. 


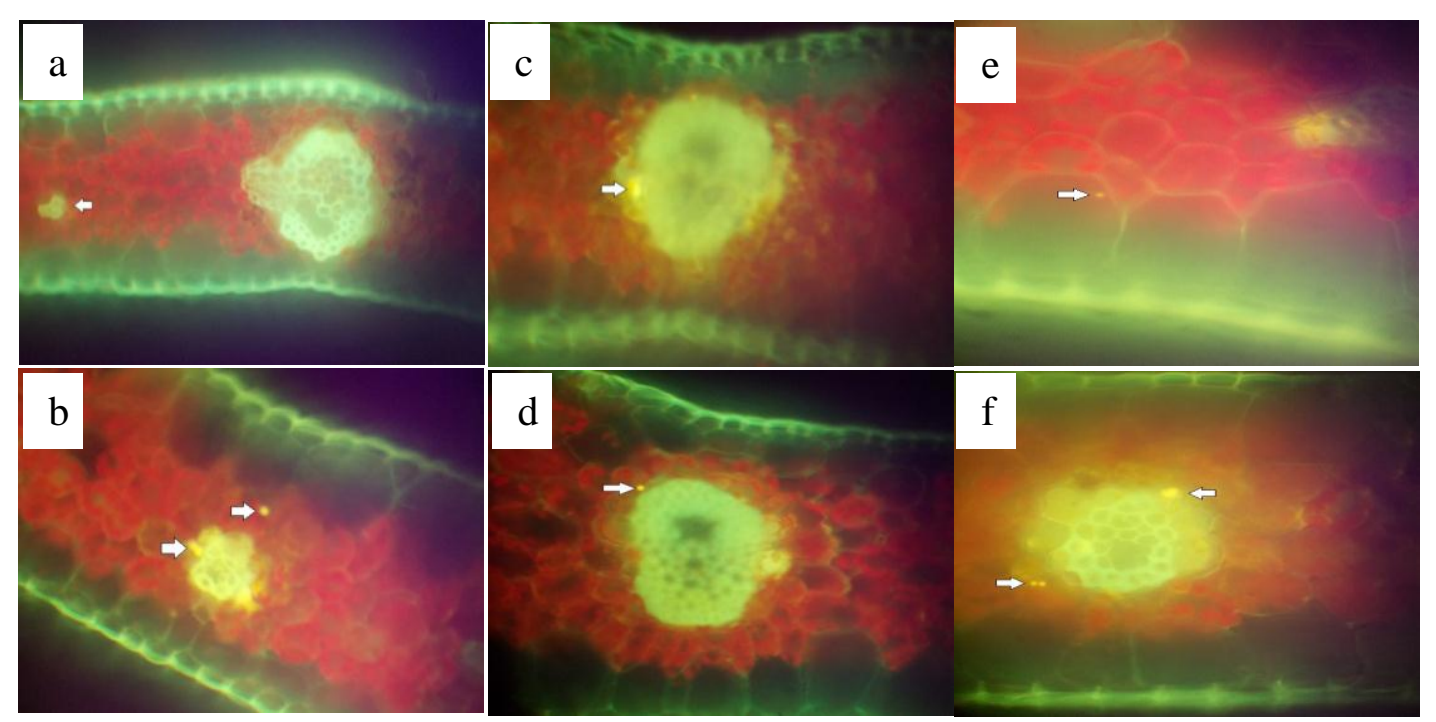

Gambar 1. Keberadaan koloni bakteri diazotrof endofit di jaringan daun bibit kelapa sawit

Keterangan : (a) koloni isolat 1 pada jaringan daun 1 JSA; (b) koloni isolat 1 pada jaringan daun $3 \mathrm{JSA}$; (c) koloni isolat 2 pada jaringan daun 1 JSA (d) koloni isolat 2 pada jaringan daun 3 JSA (e) koloni isolat 3 pada jaringan daun 1 JSA (f) koloni isolat 3 pada jaringan daun 3 JSA.

\section{Peubah Keragaan Tanaman}

\section{Diameter Bonggol}

Hasil analisis statistik terhadap diameter bonggol bibit kelapa sawit menunjukkan setiap perlakuan berbeda nyata dalam meningkatkan diameter bonggol bibit kelapa sawit sejak bibit berumur 12 MST hingga 18 MST (Tabel 1). Corley (1976) menyatakan bahwa proses fotosintesis bibit kelapa sawit mulai efektif sekitar 45 hari setelah perkecambahan, sehingga perbedaan pertumbuhan bibit kelapa sawit akibat perbedaan perlakuan akan terlihat pada periode setelahnya.

Hasil terbaik diameter bonggol bibit kelapa sawit dominan ditunjukkan oleh kombinasi perlakuan aplikasi isolat bakteri diazotrof endofit tanpa pemberian pupuk $\mathrm{N}$ (N0). Diameter bonggol bibit kelapa sawit yang terbesar dicapai pada perlakuan isolat 3 (NOI3) diikuti oleh perlakuan isolat 2 (NOI2) dan isolat 1 (NOI1). Sementara diameter bonggol terendah ditunjukkan oleh perlakuan tanpa aplikasi isolat bakteri dan tanpa pemupukan $\mathrm{N}$ (NOIO). Di sisi lain terlihat kecenderungan diameter bonggol bibit kelapa sawit yang diberi perlakuan isolat bakteri diazotrof endofit semakin menurun seiring dengan penambahan dosis pupuk $\mathrm{N}$. Hal ini menunjukkan efektivitas asosiasi bakteri diazotrof endofit semakin menurun dengan keberadaan pupuk N. Berdasarkan percobaannya, Triplett (1996) membuktikan bahwa tanaman tebu yang mendapat perlakuan pupuk nitrogen dalam jumlah yang tinggi kehilangan kemampuannya dalam berasosiasi dengan bakteri diazotrof endofit ditandai dengan menurunnya jumlah populasi bakteri diazotrof endofit di dalam jaringan tanaman. Penurunan kemampuan asosiasi bakteri diazotrof endofit dengan tanaman diduga menjadi penyebab menurunnya peran bakteri diazotrof endofit sebagai penambat dan penghasil nitrogen (Lee et al., 2000; Cruz et al., 2001) serta penghasil fitohormon (Feng et al., 2006) bagi bibit kelapa sawit.

\section{Tinggi Tanaman}

Hasil analisis statistik terhadap peubah tinggi tanaman bibit kelapa sawit menunjukkan setiap perlakuan berbeda nyata dalam meningkatkan tinggi bibit kelapa sawit sejak bibit berumur 14 MST hingga 18 MST (Tabel 2). Pertumbuhan tinggi tanaman menunjukkan pola yang sama dengan pertumbuhan diameter bonggol.

Tabel 2. memperlihatkan tinggi bibit kelapa sawit terbaik dominan ditunjukkan oleh perlakuan isolat bakteri diazotrof endofit tanpa pemberian pupuk $\mathrm{N}$ yaitu perlakuan aplikasi isolat 1 (NOI1) diikuti oleh perlakuan isolat 2 (NOI2) dan isolat 3 (NOI3). Pertumbuhan tinggi tanaman menunjukkan pola yang sama dengan pertumbuhan diameter bonggol bibit kelapa sawit yang diberi perlakuan isolat bakteri diazotrof endofit yaitu cenderung semakin menurun seiring dengan penambahan dosis pupuk nitrogen. Hal ini mendukung dugaan bahwa keberadaan pupuk $\mathrm{N}$ dalam jumlah yang besar di dalam jaringan tanaman akan menurunkan kemampuan isolat bakteri yang diuji untuk berasosiasi dengan bibit kelapa sawit. 
Tabel 1. Pengaruh pemupukan $\mathrm{N}$ dan aplikasi isolat bakteri diazotrof endofit terhadap diameter bonggol bibit kelapa sawit

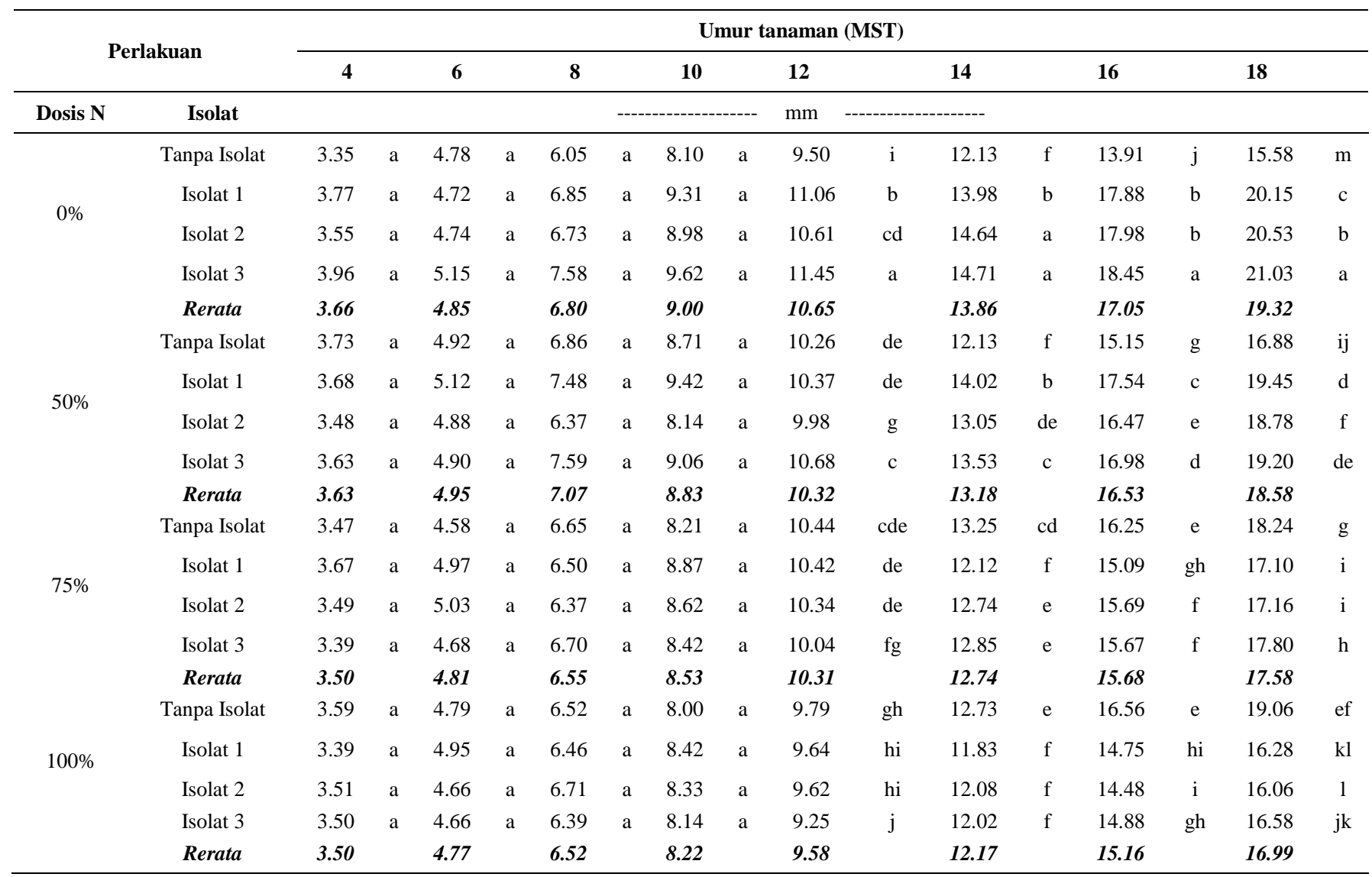

* angka-angka yang diikuti oleh huruf kecil yang sama dalam satu kolom menunjukkan perbedaan yang tidak nyata menurut DMRT 5\% $\mathrm{N} 0=0 \% ; \mathrm{N} 1=50 \% ; \mathrm{N} 2=75 \% ; \mathrm{N} 3=100 \%$

Tabel 2. Pengaruh pemupukan $\mathrm{N}$ dan aplikasi isolat bakteri diazotrof endofit terhadap tinggi bibit kelapa sawit

\begin{tabular}{|c|c|c|c|c|c|c|c|c|c|c|c|c|c|c|c|c|c|}
\hline \multirow{2}{*}{\multicolumn{2}{|c|}{ Perlakuan }} & \multicolumn{16}{|c|}{ Umur tanaman (MST) } \\
\hline & & \multicolumn{2}{|l|}{4} & \multicolumn{2}{|l|}{6} & \multicolumn{2}{|l|}{8} & \multicolumn{2}{|l|}{10} & \multicolumn{2}{|l|}{12} & \multirow[t]{2}{*}{14} & \multicolumn{3}{|c|}{16} & \multicolumn{2}{|l|}{18} \\
\hline Dosis N & Isolat & & & & & & & - & 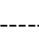 & cm ----- & & & & & & & \\
\hline \multirow{4}{*}{$0 \%$} & Tanpa Isolat & 9.34 & $\mathrm{a}$ & 14.77 & $\bar{a}$ & 18.52 & $\mathrm{a}$ & 20.47 & $\mathrm{a}$ & 24.26 & $\mathrm{a}$ & 29.10 & $\mathrm{f}$ & 31.60 & i & 36.13 & hi \\
\hline & Isolat 1 & 9.83 & a & 15.65 & $\mathrm{a}$ & 19.69 & $\mathrm{a}$ & 22.48 & $\mathrm{a}$ & 27.97 & $\mathrm{a}$ & 32.71 & $\mathrm{ab}$ & 37.63 & $\mathrm{a}$ & 43.91 & $\mathrm{a}$ \\
\hline & Isolat 2 & 9.82 & $\mathrm{a}$ & 16.35 & $\mathrm{a}$ & 19.56 & $\mathrm{a}$ & 22.53 & $\mathrm{a}$ & 27.63 & $\mathrm{a}$ & 33.37 & $a b$ & 36.66 & $\mathrm{~b}$ & 42.98 & $\mathrm{~b}$ \\
\hline & Isolat 3 & 9.26 & $\mathrm{a}$ & 15.95 & $\mathrm{a}$ & 20.02 & $\mathrm{a}$ & 22.68 & $\mathrm{a}$ & 27.69 & $\mathrm{a}$ & 33.08 & $\mathrm{ab}$ & 36.77 & $\mathrm{~b}$ & 42.82 & $\mathrm{~b}$ \\
\hline \multirow{6}{*}{$50 \%$} & Rerata & 9.56 & & 15.68 & & 19.45 & & 22.04 & & 26.89 & & 32.06 & & 35.66 & & 41.46 & \\
\hline & Tanpa Isolat & 9.41 & $\mathrm{a}$ & 15.58 & $\mathrm{a}$ & 19.35 & $\mathrm{a}$ & 22.83 & $\mathrm{a}$ & 27.06 & $\mathrm{a}$ & 30.28 & de & 33.25 & $\mathrm{~h}$ & 36.51 & $\mathrm{gh}$ \\
\hline & Isolat 1 & 9.92 & a & 15.66 & $\mathrm{a}$ & 19.07 & $\mathrm{a}$ & 22.43 & a & 27.53 & a & 33.24 & $\mathrm{ab}$ & 35.96 & $\mathrm{c}$ & 40.06 & $\mathrm{c}$ \\
\hline & Isolat 2 & 9.67 & $\mathrm{a}$ & 15.16 & $\mathrm{a}$ & 19.97 & $\mathrm{a}$ & 22.56 & a & 26.88 & a & 31.62 & $\mathrm{c}$ & 35.44 & $\mathrm{~cd}$ & 38.77 & $\mathrm{~d}$ \\
\hline & Isolat 3 & 9.73 & $\mathrm{a}$ & 15.27 & $\mathrm{a}$ & 19.10 & $\mathrm{a}$ & 22.54 & a & 27.22 & $\mathrm{a}$ & 31.82 & $\mathrm{c}$ & 35.27 & cde & 39.93 & $\mathrm{c}$ \\
\hline & Rerata & 9.68 & & 15.41 & & 19.37 & & 22.59 & & 27.17 & & 31.74 & & 34.98 & & 38.81 & \\
\hline \multirow{4}{*}{$75 \%$} & Tanpa Isolat & 9.14 & $\mathrm{a}$ & 14.87 & $\mathrm{a}$ & 18.04 & $\mathrm{a}$ & 21.30 & a & 26.08 & a & 32.60 & $\mathrm{~b}$ & 35.03 & def & 39.50 & $\mathrm{c}$ \\
\hline & Isolat 1 & 9.33 & a & 14.38 & $\mathrm{a}$ & 18.48 & $\mathrm{a}$ & 21.20 & a & 25.79 & a & 29.73 & ef & 34.84 & defg & 37.05 & fg \\
\hline & Isolat 2 & 9.86 & a & 15.53 & $\mathrm{a}$ & 19.05 & $\mathrm{a}$ & 22.23 & a & 27.23 & a & 31.61 & $\mathrm{c}$ & 34.76 & defg & 37.52 & ef \\
\hline & Isolat 3 & 9.58 & $\mathrm{a}$ & 14.47 & $\mathrm{a}$ & 18.68 & $\mathrm{a}$ & 21.85 & $\mathrm{a}$ & 26.80 & $\mathrm{a}$ & 30.90 & d & 34.31 & $\mathrm{fg}$ & 37.78 & ef \\
\hline \multirow{6}{*}{$100 \%$} & Rerata & 9.48 & & 14.81 & & 18.56 & & 21.64 & & 26.48 & & 31.21 & & 34.74 & & 37.96 & \\
\hline & Tanpa Isolat & 8.81 & $\mathrm{a}$ & 15.10 & $\mathrm{a}$ & 18.33 & $\mathrm{a}$ & 21.40 & $\mathrm{a}$ & 26.80 & $\mathrm{a}$ & 30.41 & de & 34.09 & $\mathrm{~g}$ & 40.08 & $\mathrm{c}$ \\
\hline & Isolat 1 & 9.33 & $\mathrm{a}$ & 15.32 & $\mathrm{a}$ & 18.47 & $\mathrm{a}$ & 21.93 & a & 26.37 & $\mathrm{a}$ & 30.73 & $\mathrm{~d}$ & 33.36 & $\mathrm{~h}$ & 35.56 & $\mathrm{i}$ \\
\hline & Isolat 2 & 8.78 & a & 14.76 & $\mathrm{a}$ & 17.97 & $\mathrm{a}$ & 21.72 & $\mathrm{a}$ & 26.07 & $\mathrm{a}$ & 29.37 & $\mathrm{f}$ & 33.18 & $\mathrm{~h}$ & 35.60 & $\mathrm{i}$ \\
\hline & Isolat 3 & 9.44 & $\mathrm{a}$ & 15.29 & $\mathrm{a}$ & 18.52 & $\mathrm{a}$ & 21.88 & $\mathrm{a}$ & 26.56 & $\mathrm{a}$ & 30.81 & $\mathrm{~d}$ & 34.52 & efg & 36.96 & $\mathrm{fg}$ \\
\hline & Rerata & 9.09 & & 15.12 & & 18.32 & & 21.73 & & 26.45 & & 30.33 & & 33.79 & & 37.05 & \\
\hline
\end{tabular}

* angka-angka yang diikuti oleh huruf kecil yang sama dalam satu kolom menunjukkan perbedaan yang tidak nyata menurut DMRT 5\% $\mathrm{N} 0=0 \% ; \mathrm{N} 1=50 \% ; \mathrm{N} 2=75 \% ; \mathrm{N} 3=100 \%$ 


\section{Bobot Kering Jaringan Tanaman}

Hasil analisis statistik terhadap bobot kering jaringan tanaman kelapa sawit menunjukkan setiap perlakuan berbeda nyata dalam meningkatkan bobot kering jaringan tanaman bibit kelapa sawit seperti terlihat pada Tabel 3.

Tabel 3. Berat kering jaringan tanaman bibit kelapa sawit pada interaksi perlakuan pemberian empat taraf dosis pupuk Nitrogen dengan empat isolat bakteri diazotrof endofit.

\begin{tabular}{|c|c|c|c|c|c|c|c|}
\hline \multirow{2}{*}{\multicolumn{2}{|c|}{ Perlakuan }} & \multicolumn{6}{|c|}{ Berat kering jaringan } \\
\hline & & \multicolumn{2}{|c|}{ Akar } & \multicolumn{2}{|c|}{ Tajuk } & \multicolumn{2}{|c|}{ Total } \\
\hline $\begin{array}{c}\text { Dosis } \\
\mathbf{N}\end{array}$ & Isolat & & & & & & \\
\hline \multirow{4}{*}{$0 \%$} & Tanpa Isolat & 0.77 & $\mathrm{j}$ & 4.00 & $\mathrm{j}$ & 4.77 & $\mathrm{j}$ \\
\hline & Isolat 1 & 3.23 & a & 6.87 & a & 10.10 & $\mathrm{a}$ \\
\hline & Isolat 2 & 3.14 & a & 6.50 & $\mathrm{~b}$ & 9.63 & $\mathrm{~b}$ \\
\hline & Isolat 3 & 3.06 & $\mathrm{~b}$ & 6.86 & $\mathrm{a}$ & 9.92 & $\mathrm{a}$ \\
\hline \multirow{6}{*}{$50 \%$} & Rerata & 2.55 & & 6.06 & & 8.61 & \\
\hline & Tanpa Isolat & 1.03 & $\mathrm{~g}$ & 4.50 & $\mathrm{~h}$ & 5.52 & $\mathrm{~h}$ \\
\hline & Isolat 1 & 1.42 & d & 5.96 & $\mathrm{c}$ & 7.38 & d \\
\hline & Isolat 2 & 1.29 & e & 5.49 & $\mathrm{e}$ & 6.78 & $\mathrm{e}$ \\
\hline & Isolat 3 & 1.39 & d & 5.81 & d & 7.19 & d \\
\hline & Rerata & 1.28 & & 5.44 & & 6.72 & \\
\hline \multirow{4}{*}{$75 \%$} & Tanpa Isolat & 1.13 & $\mathrm{f}$ & 5.27 & $\mathrm{f}$ & 6.39 & $\mathrm{f}$ \\
\hline & Isolat 1 & 1.05 & $\mathrm{~g}$ & 4.69 & gh & 5.73 & gh \\
\hline & Isolat 2 & 1.00 & $\mathrm{~h}$ & 4.96 & $\mathrm{~g}$ & 5.96 & $\mathrm{~g}$ \\
\hline & Isolat 3 & 1.00 & $\mathrm{~h}$ & 4.98 & $\mathrm{~g}$ & 5.98 & $\mathrm{~g}$ \\
\hline \multirow{6}{*}{$100 \%$} & Rerata & 1.04 & & 4.97 & & 6.02 & \\
\hline & Tanpa Isolat & 2.67 & $\mathrm{c}$ & 5.51 & $\mathrm{e}$ & 8.18 & $\mathrm{c}$ \\
\hline & Isolat 1 & 0.95 & $\mathrm{i}$ & 4.27 & $\mathrm{i}$ & 5.22 & $\mathrm{i}$ \\
\hline & Isolat 2 & 0.93 & $\mathrm{i}$ & 4.30 & $\mathrm{i}$ & 5.23 & $\mathrm{i}$ \\
\hline & Isolat 3 & 1.01 & $\mathrm{~h}$ & 4.48 & hi & 5.49 & hi \\
\hline & Rerata & 1.39 & & 4.64 & & 6.03 & \\
\hline
\end{tabular}

* angka-angka yang diikuti oleh huruf kecil yang sama dalam satu kolom menunjukkan perbedaan yang tidak nyata menurut DMRT 5\% $\mathrm{N} 0=0 \% ; \mathrm{N} 1=50 \% ; \mathrm{N} 2=75 \% ; \mathrm{N} 3=100 \%$

Data menunjukkan perlakuan isolat berpengaruh signifikan pada bobot kering akar, bobot kering tajuk dan bobot kering total. Hasil terbaik bobot kering akar, tajuk dan total didapat dari perlakuan pemberian isolat tanpa pemupukan N. Peningkatan bobot kering tanaman lebih disebabkan adanya keseimbangan kadar hara dan hormon dalam jaringan tanaman. Kehadiran isolat bakteri diazotrof endofit dalam jaringan tanaman mampu memberikan asupan $\mathrm{N}$ dalam jumlah yang optimum dan stabil, menghasilkan fitohormon yang juga meningkatkan daya tahan terhadap patogen. Keberadaan $\mathrm{N}$ sangat penting dalam pertumbuhan tanaman karena kedudukannya dalam proses biokimia tanaman sebagai unsur esensial pada pembentukan sel, penyusunan protein, sitoplasma, klorofil, dan komponen sel lainnya.

Kecenderungan penurunan pertumbuhan berat kering akar, berat kering tajuk dan berat kering total bibit kelapa sawit yang diberi perlakuan isolat bakteri diazotrof endofit akibat penambahan pupuk nitrogen juga semakin memperkuat dugaan bahwa seluruh isolat bakteri diazotrof endofit yang diuji cukup sensitif terhadap keberadaan $\mathrm{N}$ yang tinggi di dalam jaringan tanaman.

\section{SIMPULAN}

Aplikasi isolat bakteri diazotrof endofit tanpa pemupukan $\mathrm{N}$ pada bibit kelapa sawit mampu meningkatkan pertumbuhan diameter bonggol, tinggi bibit dan berat kering bibit kelapa sawit. Kemampuan asosiasi isolat bakteri diazotrof endofit yang diuji semakin menurun dengan keberadaan pupuk $\mathrm{N}$ dalam dosis tinggi ditandai dengan penurunan pertumbuhan vegetatif bibit kelapa sawit.

\section{DAFTAR PUSTAKA}

Barac, T., S. Taghavi, B. Borremann, A. Provoost, L. Oeyen, J.V. Colpaert, J. Vangronsveld, and D. van der Lelie. 2004. Enginered endophytic bacteria improve phytoremediation of water-soluble, volatile, organic pollutants. Nature Biotechnology, 22: $583-588$.

Corley, R.H.V. 1976. Oil Palm Research. Elsevier Scientific Publishing Company, Amsterdam. p. 2530 .

Cruz, L.M., E.M. Souza, O.B. Weber, J.I. Baldani, J, Dobereiner, and F.O. Pedrosa. 2001. 16S ribosomal DNA characterization of nitrogen-fixing bacteria isolated from Banana (Musa spp.) and Pineapple (Ananas comosus (L) Merril). Applied and Environmental Microbiology, 2375-2379.

Feng, Y., D. Shen, dan W. Song. 2006. Rice endophyte Pantoea agglomerans YS19 promotes host plant growth and affects allocations of host photosynthates. J. App. Microbiology., 100: 938945.

James, E.K., F.L. Olivares, A.L.M. de Oliveira, F.B. dos Reis Jr, L.G. da Silva, and V.M. Reis. 2001. Further observations on the interaction between sugar cane and gluconacetobacter diazotrophicus under laboratory and greenhouse conditions. Journal of Experimental Botany, 52: 747-760.

Lee, Sunhee, A. Reth, D. Meletzus, M. Sevilla, and C. Kennedy. 2000. Characterization of a major cluster of nif, fix and associated genes in a sugarcane endophyte, Acetobacter diazotrophicus. Journal Bacteriology, 182: 7088-7091.

Mattjik, A.A., dan I.M. Sumertajaya. 2006. Perancangan Percobaan dengan Aplikasi SAS dan Minitab. IPB Pr., Bogor. 271 hlm.

Muthukumarasamy, R. G. Revathi, S. Seshadri, and C. Lakshminarasimhan. 2002. Gluconacetobacter diazotrophicus (syn.Acetobacter diazotrophicus), a 
promising diazotrophic endophyte in tropic. Current Science, 83: 137-145.

Reiter, B., U. Pfeifer, H. Schwab, and A. Sessitsch. 2002. Response of endophytic bacterial communities in potato plants to infections with erwinia carotovora subsp. atroseptica. Applied and Environmental Microbiology, 68 : 2261-2268.

Triplett, E.W. 1996. Diazotrophic endophytes: progress and prospects for nitrogen fixation in monocots. Plant and Soil, 186: $29-38$.

Urquiaga, S., K.H.S. Cruz, and R.M. Boddey. 1992. Contribution of nitrogen fixation to sugarcane: nitrogen-15 and nitrogen balance estimates. Soil Science Society of America Journal, 56: 105 - 114.

Widayati, W.E. 2005. Bakteri diazotrof endofit pada tanaman tebu (Saccharum officinarum L.) identifikasi dan mekanisme asosiasi [Disertasi]. Universitas Gadjah Mada. Hal: 2-3, 41-44.

Zinniel, D.K., P. Lambrecht, N.B. Harris, Z. Feng, D. Kuczmarski, P. Higley, C.A. Ishimaru, A. Arunakumari, R.G. Barletta, and A.K. Vidaver. 2002. Isolation and characterization of endophytic colonizing bacteria from agronomic crops and prairie plants. Applied and Environmental Microbiology, 68: 2198-2208. 